\title{
Leishmania donovani nucleoside hydrolase terminal domains in cross-protective immunotherapy against Leishmania amazonensis murine infection
}

\section{Dirlei Nico ${ }^{1}$, Daniele Crespo Gomes ${ }^{1}$, lam Palatnik-de-Sousa ${ }^{2}$, Alexandre Morrot ${ }^{3}$, Marcos Palatnik ${ }^{4}$ and Clarisa Beatriz Palatnik-de-Sousa ${ }^{1 *}$}

\author{
Laboratório de Biologia e Bioquímica de Leishmania, Departamento de Microbiologia Geral, Instituto de Microbiologia Paulo de Góes, Universidade Federal do Rio \\ de Janeiro, Rio de Janeiro, Brazil \\ 2 Programa de Pós Graduação em Metrologia, Laboratório de Biometrologia, Pontifícia Universidade Católica do Rio de Janeiro, Rio de Janeiro, Brazil \\ ${ }^{3}$ Laboratório de Imunologia, Instituto de Microbiologia Paulo de Góes, Universidade Federal do Rio de Janeiro, Rio de Janeiro, Brazil \\ 4 Programa de Pós Graduação em Clínica Médica, Faculdade de Medicina, Universidade Federal do Rio de Janeiro, Rio de Janeiro, Brazil
}

\section{Edited by:}

Nahid Ali, Indian Institute of Chemical

Biology, India

\section{Reviewed by:}

Hira Nakhasi, Food and Drug Administration, USA

Benjamin M. J. Owens, University of Oxford, UK

\section{${ }^{*}$ Correspondence}

Clarisa Beatriz Palatnik-de-Sousa, Laboratório de Biologia e Bioquímica de Leishmania, Instituto de Microbiologia Paulo de Góes, CCS Universidade Federal do Rio de Janeiro, Avda. Carlos Chagas 373, Caixa Postal 68040, Cidade Universitária, Ilha do Fundão, Rio de Janeiro, Rio de Janeiro CEP

21941-902, Brazil

e-mail:immgcpa@micro.ufrj.br
Nucleoside hydrolases of the Leishmania genus are vital enzymes for the replication of the DNA and conserved phylogenetic markers of the parasites. Leishmania donovani nucleoside hydrolase $(\mathrm{NH} 36)$ induced a main $\mathrm{CD}^{+} \mathrm{T}$ cell driven protective response against $L$. chagasi infection in mice which is directed against its C-terminal domain. In this study, we used the three recombinant domains of NH36: N-terminal domain (F1, amino acids 1-103), central domain (F2 aminoacids 104-198), and C-terminal domain (F3 amino acids 199-314) in combination with saponin and assayed their immunotherapeutic effect on Balb/c mice previously infected with $L$. amazonensis. We identified that the $F 1$ and $F 3$ peptides determined strong cross-immunotherapeutic effects, reducing the size of footpad lesions to 48 and $64 \%$, and the parasite load in footpads to 82.6 and $81 \%$, respectively. The F3 peptide induced the strongest anti-NH36 antibody response and intradermal response (IDR) against $L$. amazonenis and a high secretion of IFN- $\gamma$ and TNF- $\alpha$ with reduced levels of IL-10. The F1 vaccine, induced similar increases of IgG2b antibodies and IFN- $\gamma$ and TNF- $\alpha$ levels, but no IDR and no reduction of IL-10. The multiparameter flow cytometry analysis was used to assess the immune response after immunotherapy and disclosed that the degree of the immunotherapeutic effect is predicted by the frequencies of the $\mathrm{CD}^{+}$and $\mathrm{CD}^{+} \mathrm{T}$ cells producing IL-2 or TNF- $\alpha$ or both. Total frequencies and frequencies of double-cytokine CD4 $T$ cell producers were enhanced by F1 and F3 vaccines. Collectively, our multifunctional analysis disclosed that immunotherapeutic protection improved as the CD4 responses progressed from $1+$ to $2+$, in the case of the $\mathrm{F} 1$ and $\mathrm{F} 3$ vaccines, and as the CD8 responses changed qualitatively from $1+$ to $3+$, mainly in the case of the F1 vaccine, providing new correlates of immunotherapeutic protection against cutaneous leishmaniasis in mice based on T-helper $\mathrm{TH} 1$ and $\mathrm{CD}^{+}$mediated immune responses.

Keywords: visceral leishmaniasis, cutaneous leishmaniasis, diffuse cutaneous leishmaniasis, crossimmunotherapy, nucleoside hydrolases, recombinant vaccines

\section{INTRODUCTION}

Leishmaniasis is a complex of vector-borne protozoan diseases the etiological agents of which belong to the Leishmania genus. The global incidence and prevalence of leishmaniasis is increasing. The main clinical syndromes of leishmaniasis are: cutaneous (CL), diffuse cutaneous (DCL), mucocutaneous (MCL), and visceral (VL) (1). While CL accounts for approximately $0.7-1.2$ million cases per year, which is more than $50 \%$ of the new cases of leishmaniasis (2). Most of the CL cases occur in the Mediterranean ( 85,555 cases/year), the Americas (66,941 cases/year), and the Middle East to Central Asia (61,013 cases/year) (2). The 10 countries with the highest estimated number of cases are: Afghanistan, Algeria, Colombia, Brazil, Iran, Syria, Ethiopia, North Sudan, Costa Rica, and Peru and together they account for $70-75 \%$ of the estimated global incidence of CL (2). The disease causes skin ulcers at the site of the sand-fly bite, usually on exposed parts of the body, such as the face, neck, arms, and legs and develops an active $\mathrm{T}$ cell mediated immune response that plays a pivotal role in the processes in the cure or in the aggravation of the disease (3).VL, on the other hand, has approximately $0.2-0.4$ million new cases per year (2) and is the most severe clinical syndrome of leishmaniasis characterized by hepato-splenomegaly, malaise, cachexia, fever, hypergammaglobulinemia, anemia, and the progressive suppression of the T cell mediated immune response. If left untreated, the disease has a high mortality rate mainly due to immunosuppression and secondary infections. Indeed, anergy to leishmanial antigens and negative skin tests have been reported in cases of VL caused by Leishmania donovani and L. infantum/chagasi (4-6), 
and DCL caused by L. amazonensis (7) while a strong TH1 proinflammatory response has been detected in cases of CL (8) and MCL caused by L. braziliensis (9).

Since the chemotherapy of leishmaniasis is highly toxic and the few available therapeutic drugs are only partially effective $(10,11)$, due to an increase in the resistance of parasites to antibiotics, a protective vaccine would be important not only for prophylaxis but also for the immunotherapy of the disease. The success of immunotherapy in the control of human CL leishmaniasis with the use of crude parasite vaccines combined to BCG has been reported since the 80 s (12-14). Furthermore, immunochemotherapy against human CL leishmaniasis has been reported to reduce the time of chemotherapy needed to cure this disease in humans, thus decreasing its toxicity (15).

Since the epidemics of VL and CL are spreading on a worldwide scale, even overlapping in some areas, and no human vaccine is available yet, the development of a bivalent vaccine for the control of tegumentary and VL leishmaniasis is highly recommended. Consequently, we believe that the search for cross-protective antigens is mandatory. Recently, we developed the first licensed second generation vaccine against canine VL leishmaniasis (Leishmune ${ }^{\circledR}$ ), which contains the fucose-mannose ligand (FML) antigen of $L$. donovani in formulation with saponin (16-19), is a transmission blocking vaccine $(18,19)$ and has already determined a reduction in the incidence of the human and canine disease in Brazilian endemic areas (20). Prophylactic vaccination of dogs with Leishmune ${ }^{\circledR}$ promoted increases in the production of NO, IgG2 antibodies against FML and $L$. chagasi, intradermal reactions and proportions of $\mathrm{CD}^{+}{ }^{+}$lymphocytes, which secrete more IFN- $\gamma$ than IL-4 $(21,22)$ expressing a selective pro-inflammatory pattern (IFN- $\gamma / \mathrm{NO})$ (23). The early and persistent activation of neutrophils and monocytes have also been described (23). This increase in proportions of $\mathrm{CD}^{+} \mathrm{T}$ cells is expected for the QS21 saponin adjuvant of Leishmune ${ }^{\circledR}$ (24) and this was also described in the Leishmune ${ }^{\circledR}$ immunotherapy assays against naturally (25) and experimentally acquired canine VL leishmaniasis (26). Furthermore, the sustained or increased proportions of $\mathrm{CD}^{+}$and CD21-B lymphocytes $(25,26)$ and the reduced $\mathrm{CD}^{+} / \mathrm{CD} 25^{+} \mathrm{T}$ cell counts $(27)$ have also been described in Leishmune ${ }^{\circledR}$ vaccinated dogs.

Leishmune ${ }^{\circledR}$ canine immunotherapy, on the other hand, reduced the number of deaths and the clinical and parasitological signs of canine VL and, when used for immunochemotherapy with allopurinol, amphotericin, and enrofloxacin, promoted the sterile cure (28).

QS21 and deacylated saponins of Quillaja saponaria are the adjuvants of the Leishmune ${ }^{\circledR}$ vaccine (29). The QS21 Stimulon 1 saponin (Agenus) is also the adjuvant currently being studied in 17 human clinical programs, including four Phase 3 anti-Malaria assays, by GlaxoSmithKline. The anti-Malaria vaccine, called the RTS,S or Mosquirix, indeed contains the P. falciparum cir-cumsporozoite (CS) protein central tandem repeat and carboxy-terminal regions fused to the amino-terminus of the $\mathrm{S}$ antigen of hepatitis B virus (HBsAg) (30) and the AS01 adjuvant, which is composed of QS21 Stimulon in combination with monophosphoryl Lipid A (31). The RTS,S/AS01 vaccine co-administered with EPI vaccines provided modest protection against both clinical and severe malaria in young infants (32).

The main component of the FML antigen is the nucleoside hydrolase of L. donovani (NH36), which was the only FML component specifically recognized by the sera of patients with human VL leishmaniasis (33). NH36 is not only a vital enzyme which cleaves exogenous nucleosides to release pyrimidines or purines for the DNA synthesis and further replication of the parasite (34, 35), but also a strong antigen (36) present in the early stages of the parasite infection. It fulfills the requirements for a cross-protective antigen of a Leishmania vaccine perfectly since it is a strong phylogenetic marker Leishmania $(37,38)$ that shares high identity with the sequences of the nucleoside hydrolases of L. major (95\%) (39), L. mexicana (93\%), L. chagasi (99\%), L. infantum (99\%), L. tropica (97\%), and L. braziliensis (84\%) (40). This fact explains why a vaccine containing $\mathrm{NH} 36$, in its native form, reduced the infection by $L$. donovani (41) in mice and was characterized as an $L$. major exo-antigen (42), and in its recombinant or DNA formulations, protected mice against challenge with L. chagasi, L. mexicana (43, 44), L. amazonensis (45), and L. major (42), and dogs against challenge with L. chagasi (46). The DNA-NH36 vaccine induced a $\mathrm{TH} 1$ immune response related to the IFN- $\gamma$ expression by $\mathrm{CD} 4{ }^{+}$ $\mathrm{T}$ cells, which led to an $88 \%$ prophylactic protection against VL (43), 65-81\% against tegumentary leishmaniasis $(42,43,45)$ and $91 \%$ immunotherapy against VL leishmaniasis in the mouse model (47). Also, higher proportions of $\mathrm{CD}^{+}{ }^{-} \mathrm{NH} 36$-specific lymphocytes and higher levels of IFN- $\gamma$ and IL- 2 were found in L. chagasi infected dogs treated with NH36-DNA vaccine (46).

We recently obtained three recombinant fragment proteins representing the whole sequence of NH36: amino acids 1-103 (F1, N-terminal domain), 104-198 (F2, central domain), and 199-314 (F3, C-terminal domain) and used them in a mouse vaccination against $L$. chagasi infection in order to map the domain of $\mathrm{NH} 36$, which is the target of the adaptive immunity (48). Protection against $L$. chagasi infection in mice was determined by the C-terminal domain of NH36, which induced a main CD4 ${ }^{+}$ $\mathrm{T}$ cell mediated response with a minor contribution of $\mathrm{CD} 8^{+} \mathrm{T}$ cells. Protection induced by this C-terminal peptide was superior to that induced by the whole protein. Vaccination with the Cterminal determined the increases of antibody titers (IgM, IgG2a, IgG1, and IgG2b), frequencies of CD4 ${ }^{+}$T lymphocytes, and levels of IFN- $\gamma$ in the splenocyte supernatants. The proportions of $\mathrm{CD}^{+}{ }^{+}$and $\mathrm{CD}^{+}{ }^{+} \mathrm{T}$ lymphocytes generating IFN- $\gamma$ were higher than those generating IL-10. Antibodies of Leishmune ${ }^{\circledR}$ vaccinated dogs showed the most potent reactivity against the epitopes of the C-terminal domain. The intradermal response (IDR) against $L$. donovani antigen and the increase of TNF- $\alpha$, when compared to IL-10, expressed by $\mathrm{CD}^{+}$lymphocytes were very good correlates of vaccine induced immunity (48). Important epitopes for mice (48), human, and dog B cells (49) were also recently demonstrated in the sequence of the $\mathrm{C}$-terminal domain.

In the search for cross-protection for CL leishmaniasis, we further vaccinated mice with the NH36 domains and challenged them with L. amazonensis (48). Different from the absolute dominance of the C-terminal domain in immune protection to VL, the most severe syndrome (1), preliminary results suggest that protection 
against CL by L. amazonensis is mediated by the C-terminal and the N-terminal domain in similar proportions (48).

In the present work, we studied the immunotherapeutic effect of $\mathrm{NH} 36$ or its peptide components in a formulation with saponin, on mice infection by L. amazonensis, in order to assess which of the NH36 domains deserves to be considered as components in a future cross-therapeutic vaccine for leishmaniasis. We identified that the N-terminal and C-terminal domains of NH36 induced strong curative effects which improved, as the CD4 T cell responses shifted from single- to double-cytokine producers $\left(\mathrm{TNF}-\alpha^{+}\right.$-IL$2^{+}$), and, in the case of the $\mathrm{N}$-terminal domain vaccine, as the CD8 T cell responses shifted qualitatively from single- to triple-cytokine producers (TNF- $\alpha^{+}-\mathrm{IL}-2^{+}-\mathrm{IFN}-\gamma^{+}$).

\section{MATERIALS AND METHODS \\ ETHICAL STATEMENTS}

All experiments were reviewed and approved by the Animal Care and Use Committee of the Instituto de Biofisica Carlos Chagas Fo.-UFRJ (CAUAP-CONCEA, Brazil, IMPPG-016) and were performed according to the guidelines of the National Institutes of Health, USA. We made all efforts to minimize animal suffering.

\section{NUCLEOSIDE HYDROLASE-NH36 DOMAINS}

The sequence of DNA and amino acids of NH36 is deposited in the EMBL, GenBank ${ }^{\mathrm{TM}}$, and DDJB data bases, access number AY007193. NH36 is composed of 314 amino acids. The three peptide domains of NH36 codifying, respectively, for the amino acids 1-103 (F1), 104-198 (F2), and 199-314 (F3) were cloned in the pET28b plasmid and were expressed and chromatographed as previously described (48). A preliminary molecular model was obtained through homology modeling using the Modeller9.10 software and the data of the nucleoside hydrolase from L. major template (RCSB PDB code: 1EZR; Crystal structure of nucleoside hydrolase of L. major) (50). It is important to note that the model shown in this investigation is preliminary and not a final, optimized model. The predicted epitopes for MHC class II-IAd and IEd, haplotype $\mathrm{H} 2 \mathrm{~d} \mathrm{CD} 4^{+} \mathrm{T}$ cells, MHC class I Ld-CD8 ${ }^{+} \mathrm{T}$ cells, and $\mathrm{B}$ cells were plotted in the $\mathrm{C}$-terminal and $\mathrm{N}$-terminal moieties of the model (48). Additionally, the analysis of the solvent accessible surface area of the C-terminal, central, and $\mathrm{N}$-terminal sections of the tetramer was performed using the PyMol 1.3 software.

\section{IMMUNOTHERAPEUTIC VACCINATION IN LEISHMANIA AMAZONENSIS INFECTED MICE}

Two-month-old Balb/c mice (female) were infected with $10^{5} \mathrm{~L}$. amazonensis ( $\mathrm{pH} 8$ strain) metacyclic promastigotes isolated from hamsters and maintained in Schneider's medium in the right hind footpads (45). The evolution of lesions was monitored weekly with a caliper apparatus (Mitutoyo) and the swelling of the noninfected contra-lateral left footpads were subtracted. Six weeks after infection groups of mice received three doses of $100 \mu \mathrm{g}$ of $\mathrm{NH} 36, \mathrm{~F} 1, \mathrm{~F} 2$, or F3 recombinant proteins and $100 \mu \mathrm{g}$ of SIGMA saponin (NH36sap, F1sap, F2sap, and F3sap vaccines, respectively), at weekly intervals, in the back by the sc route, while the control group was treated with saline solution. At 9 weeks after infection sera were collected for the assay of anti-NH36 antibodies in an ELISA assay and the IDR against L. amazonensis $(\mathrm{pH}$
8) lysate (IDR) was determined in the footpads as described previously (48). Mice were euthanized with $\mathrm{CO}_{2}$ and their cellular immune response was assessed by intracellular staining (ICS), multiparameter cytometry analysis of splenocytes $(51,52)$, and by a cytokine-ELISA assay of the splenocytes supernatants. The total number of parasites in the footpad lesions was determined after sacrifice by Real Time PCR as previously described (53) using primers for L. chagasi on DNA isolated from infective promastigotes of L. amazonensis $(\mathrm{pH} \mathrm{8)}$ obtained from hamsters footpads (48).

\section{ASSESSMENT OF THE CELLULAR IMMUNE RESPONSE}

The cellular immune response was assessed using $10^{6}$ splenocytes that had been cultured in RPMI for $72 \mathrm{~h}$ in vitro at $37^{\circ} \mathrm{C}$ and $5 \%$ $\mathrm{CO}_{2}$ in the presence or absence of $5 \mu \mathrm{g}$ of NH36. The multiparameter analysis $(51,52)$ was carried out to assess the intracellular production of IL-2, TNF- $\alpha$, and IFN- $\gamma$ cytokines by $\mathrm{CD}^{+}$and $\mathrm{CD}^{+} \mathrm{T}$ lymphocytes. For this evaluation, the cells were treated with brefeldin (SIGMA) at a final concentration of $10 \mu \mathrm{g} / \mathrm{ml}$, incubated for an additional $4 \mathrm{~h}$, and then stained with rat anti-mouse CD4FITC (clone GK1.5) and CD8FITC (clone 53-6.7) monoclonal antibodies (R\&D systems, Inc.) and further stained with IFN- $\gamma$ APC, IL-2-PerCP-Cy5.5, and TNF- $\alpha$ PE monoclonal antibodies (BD-Pharmingen) as described before (48). For the ICS methods, 100,000 lymphocytes were acquired using a BD FACScalibur apparatus. Data were analyzed using the Cell Quest program. The secretion of cytokines was also evaluated in the supernatants of splenocytes by an ELISA assay as previously described (48).

\section{STATISTICAL ANALYSIS}

The Kruskal Wallis and Mann Whitney non-parametrical tests were used for comparison of means and the two-tailed Pearson bivariate analysis for the assessment of the correlation coefficient (GraphPad Prism 6 for Windows).

\section{RESULTS}

To understand more clearly how the peptide domains F1, F2, and F3 are distributed along the whole of the NH36 molecule, we obtained the preliminary model of the nucleoside hydrolase$\mathrm{NH} 36$ by homology to the model of the nucleoside hydrolase of L. major (Figure 1). Our aim was only to illustrate the molecule. The image of the molecule shows its tetramer composition, with four identical subunits. The solvent accessible surface area was computed and this disclosed the distribution of the F1, F2, and F3 domains (Figure 1A). This tridimensional surface model of the tetramer revealed that the F3 (C-terminal domain) is the domain with the largest area of exposed surface $(29,507,002 \AA)$ (Figure 1A). This is followed by the F1 (N-terminal domain) with an area of $27,132,781 \AA$. The F2 (central domain) has the smallest surface area $(19,931,451 \AA)$ and is therefore the least exposed domain (Figure 1A). The detailed monomer (Figure 4B) shows the F3 as the most exposed peptide, followed by the less exposed F1, while the F2 fragment (central domain), on the other hand, is apparently more hidden (Figure 4B). The sequence of F3 includes three predicted epitopes for $\mathrm{CD}^{+}{ }^{+} \mathrm{T}$ cells (Figure $4 \mathrm{C}$ ) and three epitopes for antibodies (Figure 4D) while the F1 shows two epitopes for $\mathrm{CD}^{+}$, one epitope for $\mathrm{CD} 8^{+} \mathrm{T}$ cells (Figure 4C), and two epitopes for antibodies (Figure 4D). 


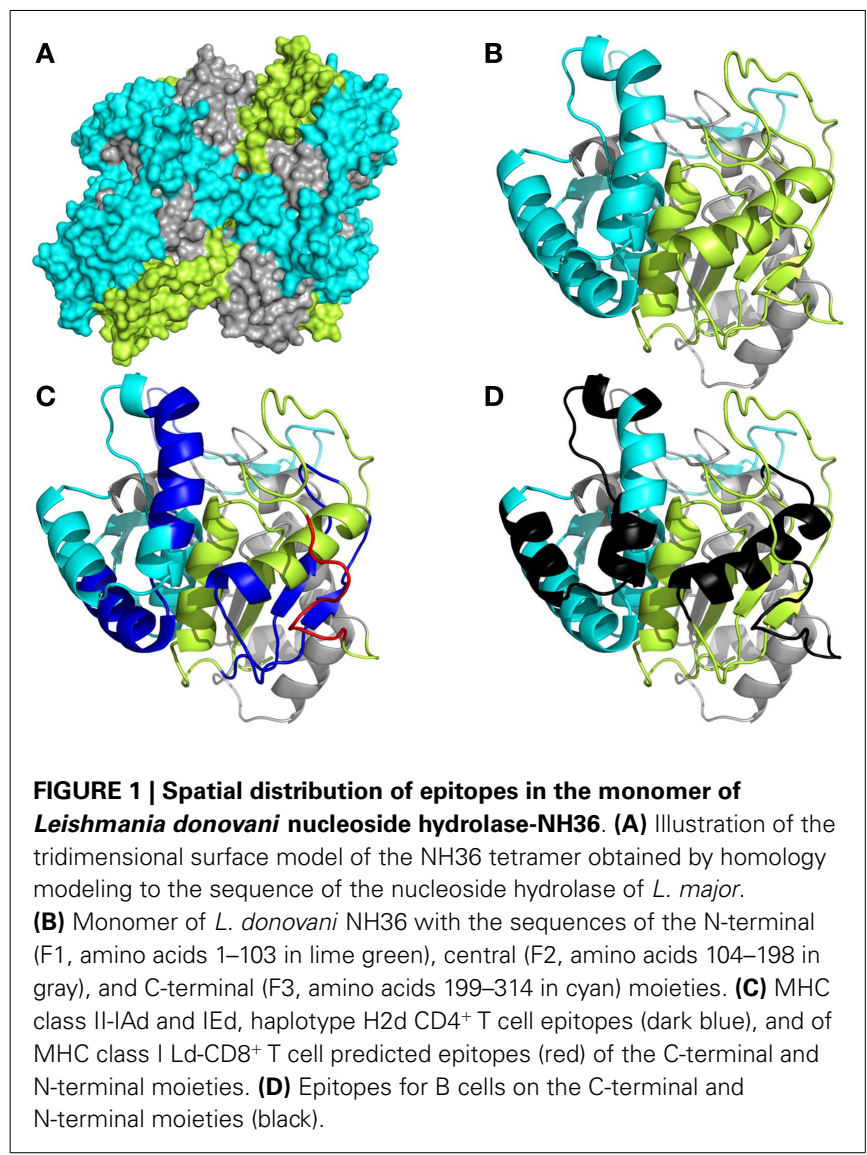

We also studied the immunotherapeutic effect of the NH36, F1, F2, and F3-saponin vaccines in mice previously infected with L. amazonensis. On week 6 after infection, when significant differences between the sizes of infected and the contra-lateral uninfected footpads were already detected, three doses of each vaccine were injected with weekly intervals. Sera samples were obtained and analyzed for anti-NH36 antibodies 1 week 9 after completing vaccination schedule (Figure $2 \mathbf{A}$ ). Significant variations were detected for all antibody classes and subtypes $(p<0.0001)$. The F3sap vaccine induced levels of anti-NH36 $\operatorname{IgA}, \operatorname{IgM}, \operatorname{IgG}$, and IgG2a antibodies as high as the NH36 vaccine and of IgG1 antibodies higher than the F2sap vaccine indicating that the main NH36 B cell epitopes involved in immunotherapy are located in the C-terminal moiety of NH36. The F1 vaccine, on the other hand, induced only IgG2b levels higher than saline controls and compatible with all other vaccines (Figure 2A).

After immunotherapy, the IDR specific response against $L$. amazonensis lysate was predominant in the $\mathrm{F} 3$ vaccinated mice, which showed an IDR as high as the one induced by the NH36 vaccine (Figure 2B). The other peptide vaccines were not different from the saline treated controls which exhibited, as expected for CL leishmaniasis, a positive and mild IDR reaction of $0.15 \mathrm{~mm}$ at $24 \mathrm{~h}$ and $0.06 \mathrm{~mm}$ at $48 \mathrm{~h}$ (Figure 2B). This result points out the pre-dominance of the epitopes present at the C-terminal domain in the generation of a cellular immune response to L. amazonensis infection.

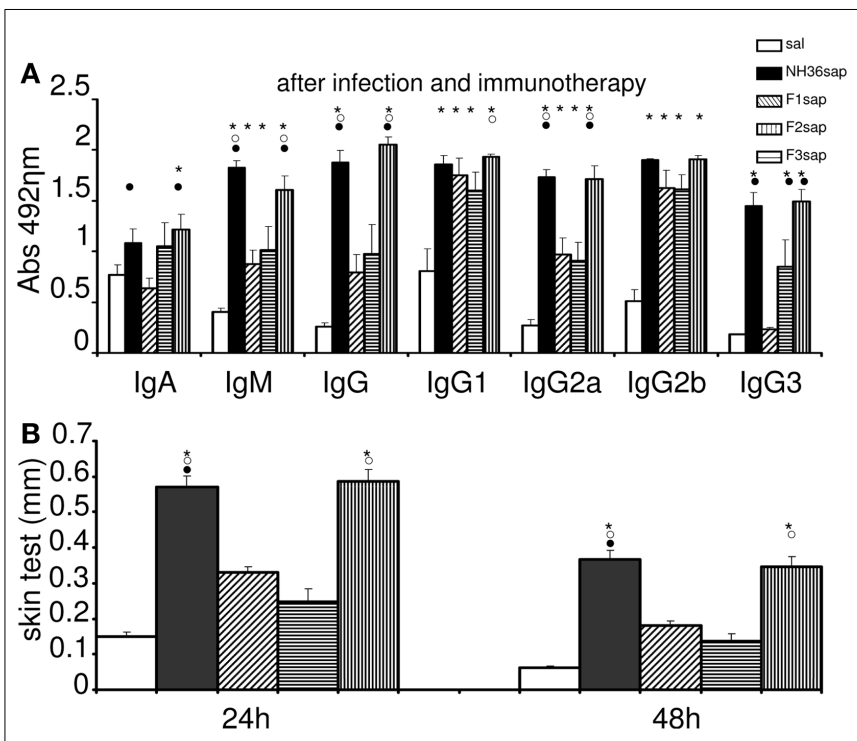

FIGURE 2 |Therapeutic vaccination, anti-NH36 antibodies, and intradermal response to $\boldsymbol{L}$. amazonenis. Six weeks after infection with $10^{5}$ metacyclic promastigotes of $L$. amazonensis in the footpads, Balb/c mice were further vaccinated with three subcutaneous doses of NH36sap, F1sap, F2sap, or F3sap at weekly intervals. Bars represent the mean \pm SE of the absorbance values of anti-NH36 antibodies from 1/100 diluted serum (A) and intradermal response to the promastigote lysate of L. amazonensis (24 and $48 \mathrm{~h}$ after antigen injection) (B) of two independent experiments with $n=6-7$ mice per treatment performed after complete vaccination. ${ }^{*} p<0.05$ different from the saline control; ${ }^{\circ} p<0.05$ different from the F2sap vaccine; $\bullet$ from the F1sap vaccine.

As a further measure of the therapeutic effect, we compared lesion development and parasite burden on week 9 after challenge. Significant differences between treatments were detected in the size of the footpad lesions along the time $(p<0.0001)$. The NH36sap $(p<0.001)$, F1sap $(p<0.05)$, and F3sap vaccines $(p<0.001)$ reduced the size of footpad lesions, along the time, to a similar extent if compared to the untreated infected saline controls. The F3sap vaccine also showed to be more therapeutic than the F2sap vaccine $(p<0.05)$ (not shown). When looking in detail at the individual footpad sizes on week 9 (Figure 3A), it was possible to observe that the best therapeutic effect was detected in the F3sap vaccinated mice, whose mean lesion size $(0.23 \mathrm{~mm})$ was $64 \%(p<0.001)$ lower than that of the saline controls $(0.64 \mathrm{~mm})$ and $48 \%(p<0.05)$ lower than that of the F2sap vaccine group $(0.44 \mathrm{~mm})$ (Figure 3A). The sizes of footpad lesions at week 9 were significantly correlated to the number of L. amazonensis parasites in lesions quantified by RTPCR, which disclosed that only the $\mathrm{N}$-terminal and C-terminal domains reduced to $82.6 \%$ $(p<0.006)$ and $81 \%(p<0.021)$, respectively, the number of parasites in lesions when compared to the control animals (Figure 3B). No difference in parasite load was detected between both vaccines $(p<0.05)$. Mice treated with F2sap, on the other hand, showed no decrease in parasite load when compared to the untreated controls $(p>0.05)$ (Figures 3A,B). None of the animals in the saline control or F2 vaccine group showed a total absence of parasites, however, three animals of the F1 and NH36 vaccines, and two 


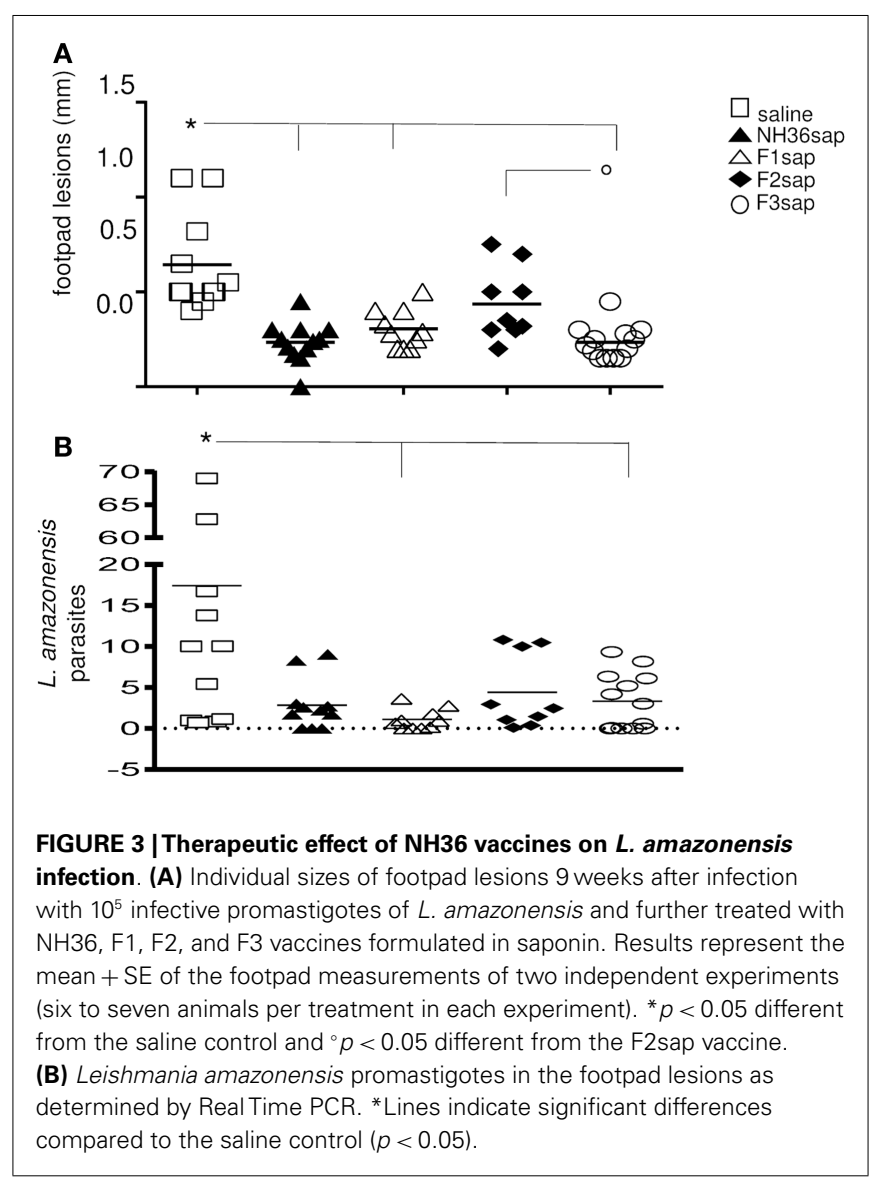

animals of the F3 vaccine showed zero parasites in their footpad lesions.

Furthermore, the cytokine levels secreted to the splenocytes supernatants after stimulation with NH36 were measured (Figure 4) and significant variations among treatments were detected for the secretion of IFN- $\gamma(p<0.001)$, TNF- $\alpha$ $(p<0.001)$, and IL-10 $(p<0.01)$ (Figures 4A-C). The NH36sap, F1sap, and F3sap vaccines induced increased levels of IFN- $\gamma$ above the saline controls ( $p<0.01$ for each vaccine) (Figure 4A) while TNF- $\alpha$ was increased by the F3sap $(p<0.05)$ and F1sap $(p<0.05)$ above the F2sap vaccine (Figure 4B). Additionally, only the NH36sap $(p<0.01)$ and F3sap $(p<0.05)$ vaccines expressed lower levels of IL-10 than the saline controls (Figure 4C). Therefore, while the $\mathrm{F} 3$ vaccine promoted a $\mathrm{TH} 1$ therapeutic response with high secretion of the pro-inflammatory cytokines IFN- $\gamma$ and TNF- $\alpha$ and low levels of the regulatory cytokine IL-10, the $F 1$ vaccine, differently, induced the increase of IFN- $\gamma$ and TNF- $\alpha$ (Figures 4A,B) but no decrease however, of the IL10 levels (Figure 4C). The analysis of the IFN- $\gamma / \mathrm{IL}-10$ ratio (Figure 4D) disclosed also that the F2sap vaccine did not differ from the saline control. The higher ratios were seen in animals treated with the NH36 and F3 vaccines, followed by the F1sap vaccine (Figure 4D). The TNF- $\alpha /$ IL-10 ratios, on the other hand were only enhanced by the NH36sap and F3sap vaccine above the levels of the saline controls and F2sap vaccine (Figure 4E).
Based on the requirements of IFN- $\gamma$ and the roles of TNF- $\alpha$ and IL-2 as effector cytokines that mediate protection, we assessed the frequency of NH36-specific IFN- $\gamma$, IL-2-, and TNF- $\alpha$-producing $\mathrm{CD}^{+}{ }^{+} \mathrm{T}$ cells after immunotherapy treatment by multiparameter cytometry analysis. We initially assessed the total frequencies of $\mathrm{CD}^{+}{ }^{+}$- T cells producing IFN- $\gamma$, IL-2-, and TNF- $\alpha$, which summarize the frequency of cells that produce each particular cytokine alone (single producers), and together with one more (double producers) and two other cytokines (triple cytokines). On week 9 after infection, significant differences between treatments in the total frequencies of TNF- $\alpha(p=0.0077)$ and IL-2-producing$\mathrm{CD} 4{ }^{+} \mathrm{T}$ cells of the spleens $(p=0.0035)$ were found (Figure 5A). The total frequencies of CD4 ${ }^{+} \mathrm{T}$ cells producing TNF- $\alpha$ and IL-2 (Figure 5A) were significantly increased above their saline controls and reached $35-36 \%$, in the case of F1sap, and $28 \%$ in the case of the F3sap vaccine, while the NH36 vaccine increased only the IL-2producing cells to $29 \%$. In agreement with that, the proportion of $\mathrm{CD}^{+}{ }^{+} \mathrm{T}$ cells producing TNF- $\alpha^{+}-\mathrm{IL}-2^{+}$was increased to 33 and $27 \%$, by the F1sap and F3sap vaccines, respectively (Figure 5B). On the other hand, the frequencies of $\mathrm{IL}_{-} 2^{+}$and TNF- $\alpha$ single cytokine producer $\mathrm{CD} 4^{+} \mathrm{T}$ cells were increased significantly, only by the F3sap vaccine to 14 and $12 \%$, respectively (Figure 5B).

In contrast to the lack of correlation seen by measuring the total frequencies of $\mathrm{CD}^{+}{ }^{+} \mathrm{IFN}-\gamma^{+}$producing cells alone or in combination with other cytokines (Figures 5A,B), which collectively developed frequencies below $1 \%$, our analysis showed a high correlation between the frequency of multifunctional (IL-2, TNF- $\alpha$, TNF- $\alpha-I L-2) \mathrm{CD}^{+} \mathrm{T}$ cells and the degree of protection. The sizes of footpad lesions (Figure 3A), which were positively correlated with the number of parasites (Figure 3B $)(R=0.7239, p<0.001)$, were negatively correlated to the total frequencies of $\mathrm{CD}^{+}$. $\mathrm{IL}^{+} 2^{+}(R=-0.3063 ; p=0.0243), \mathrm{CD}^{+}{ }^{+} \mathrm{TNF}-\alpha^{+}(R=-0.2847$; $p=0.0369), \mathrm{CD}^{+}-\mathrm{IL}-2^{+}-\mathrm{TNF}-\alpha^{+} \quad(R=-0.2964 ; p=0.0295)$ and of the CD4 ${ }^{+}-\mathrm{IL}-2^{+}(R=-0.3611 ; p=0.0068)$ single cytokine producer $T$ cell populations (Figures $5 \mathrm{~A}, \mathbf{B}$ ).

Differences in the quality of the response between vaccine groups are represented pictorially by pie charts (Figure 5C). Quantifying the fraction of the total cytokine response comprising three $(3+)$, any two $(2+)$, or any one $(1+)$ cytokine, we found that over a half of the $\mathrm{CD} 4{ }^{+}$-responses in untreated controls, NH36sap and F3sap vaccines were $1+$ cells, while $65 \%$ of the response in F1sap and F2sap vaccines were $2+$ cells.

Remarkably, and despite the low global frequency of triplecytokine and of IFN- $\gamma$ producing $\mathrm{CD}^{+}{ }^{+} \mathrm{T}$ cells (Figures $5 \mathrm{~A}, \mathbf{B}$ ), we noted a progressive 3,165 and 3,473-fold increase in the median fluorescence intensity (MFI) for IFN- $\gamma$ from CD4 ${ }^{+} \mathrm{T}$ cells that secrete all the three cytokines compared with single cytokineproducing $\mathrm{CD} 4^{+} \mathrm{T}$ cells (Figure $5 \mathrm{D}$ ) only in the animals treated with the F1sap and the F3 vaccines.

On the other hand, the multiparameter analysis of the NH36specific $\mathrm{CD}^{+} \mathrm{T}$ cell population, disclosed that the total frequencies of IL-2-producing cells were enhanced to 19, 15, and $20 \%$, respectively, by the NH36, the F1sap, and the F3sap vaccines (Figure 6A). The frequency of $\mathrm{IL}-2^{+}$single cytokine producer $\mathrm{CD}^{+} \mathrm{T}$ cells was increased (Figure 6B) above controls and to $10 \%$, by the $\mathrm{NH} 36$ vaccine. In correlation with that, the multifunctional analysis revealed that only the increase 

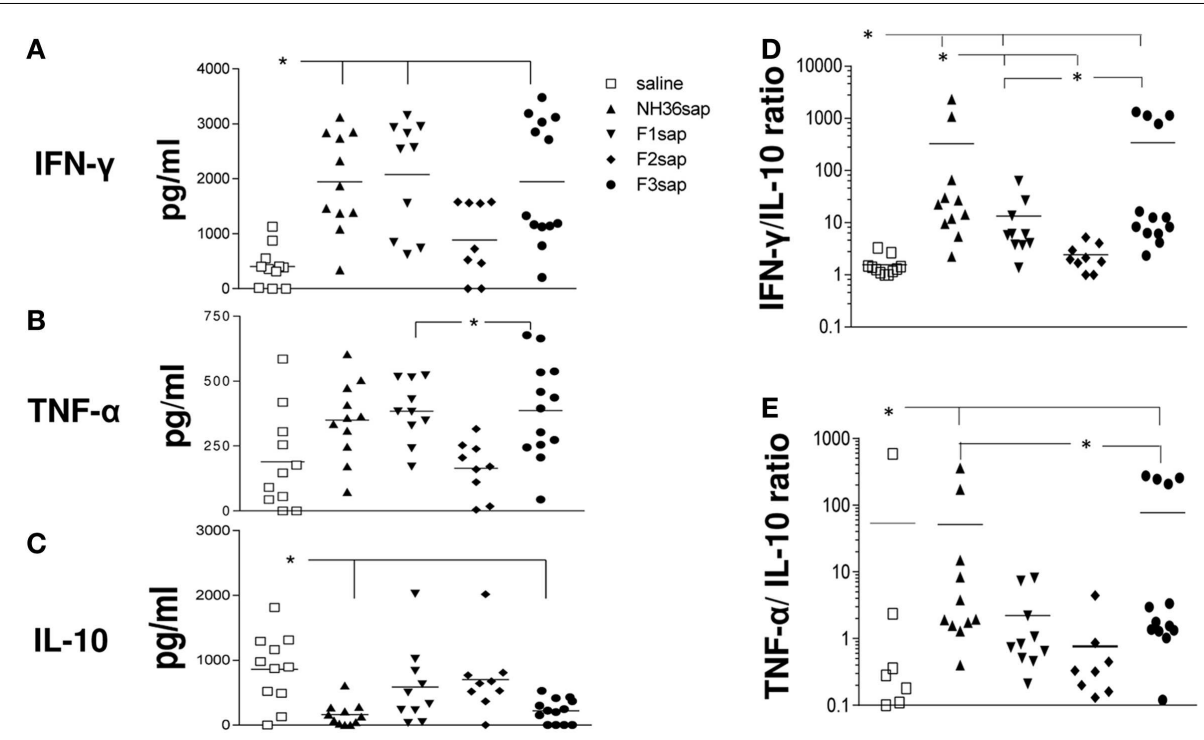

FIGURE 4 | Cytokine expression. After euthanasia, the secretion of IFN- $\gamma$, TNF- $\alpha$, and IL-10 were evaluated by an ELISA assay, in the supernatants of splenocytes, which had been incubated with $\mathrm{NH} 36$ for $72 \mathrm{~h}$. Results in (A-C) are presented as means and individual levels of secreted cytokines, expressed as picogram per milliliter, of two independent experiments (six to seven mice per treatment in each experiment) and as the IFN- $\gamma / \mathrm{IL}-10$ (D) and TNF- $\alpha / \mathrm{IL}-10$ (E) ratios. * Significant differences between treatments.
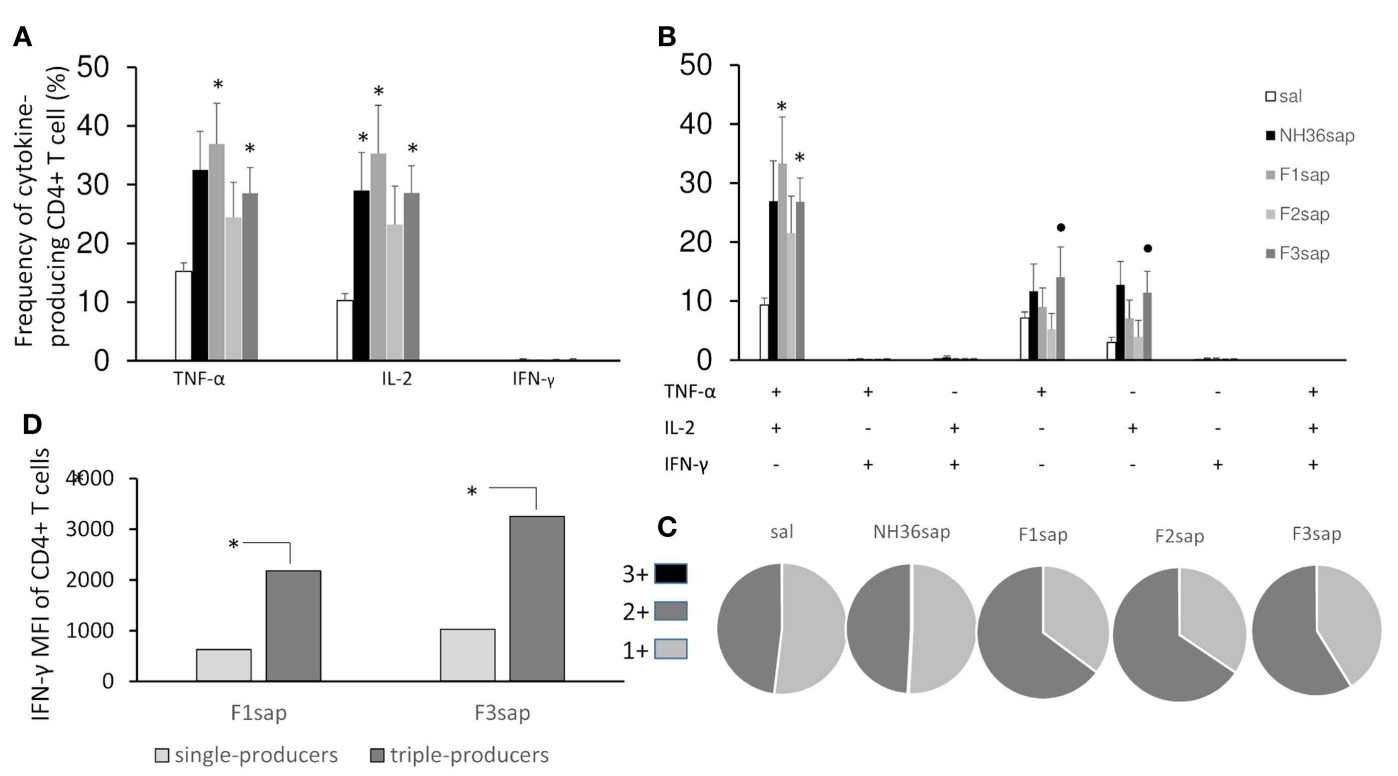

FIGURE 5 | Multifunctional analysis discloses the magnitude and quality of the $\mathrm{CD4}^{+} \mathbf{T}$ cell response. $\mathrm{NH36}$-specific cytokine production from $\mathrm{CD}^{+} \mathrm{T}$ cells of spleens of immunotherapy treated and control mice 9 weeks after infection (A-C). Multiparameter flow cytometry was used to determine (A) the total frequency of IFN- $\gamma_{-}$, IL-2-, or TNF- $\alpha$-producing CD4 ${ }^{+}$ $T$ cells, (B) the frequency of cells expressing each of the seven possible combinations of IFN- $\gamma$, IL-2, and TNF- $\alpha$, (C) the magnitude of the IFN- $\gamma$ secretion expressed by its median intensity fluorescence (MFI) in singleand triple-cytokine $\mathrm{CD} 4^{+} \mathrm{T}$ cell producers and (D) the fraction of the total response comprising cells expressing all three cytokines $(3+)$, any two cytokines $(2+)$, or any one cytokine $(1+)$. Results shown as the mean $\pm \mathrm{SE}$ of two independent experiments with $n=6-7$ in each experiment. * Significant differences from saline treated controls, •significant differences from the F2sap vaccine. of the $\mathrm{CD} 8^{+} \mathrm{T}$ cells producing IL-2 or TNF- $\alpha$ or both were predictive of the therapeutic effect of vaccination. Indeed, the total frequencies of $\mathrm{CD} 8^{+}-\mathrm{IL}-2^{+}(R=-0.4575 ; p=0.004$ and
$R=-0.4363 ; p=0.0292), \mathrm{CD}^{+}{ }^{-} \mathrm{IL}-2^{+}-\mathrm{TNF}-\alpha^{+}(R=-0.2795 ;$ $p=0.0407$ and $R=-0.3820 ; p=0.0500)$ and the CD8 ${ }^{+}$-IL$2^{+}$single cytokine populations $(R=-0.3716 ; p=0.0057$ and 

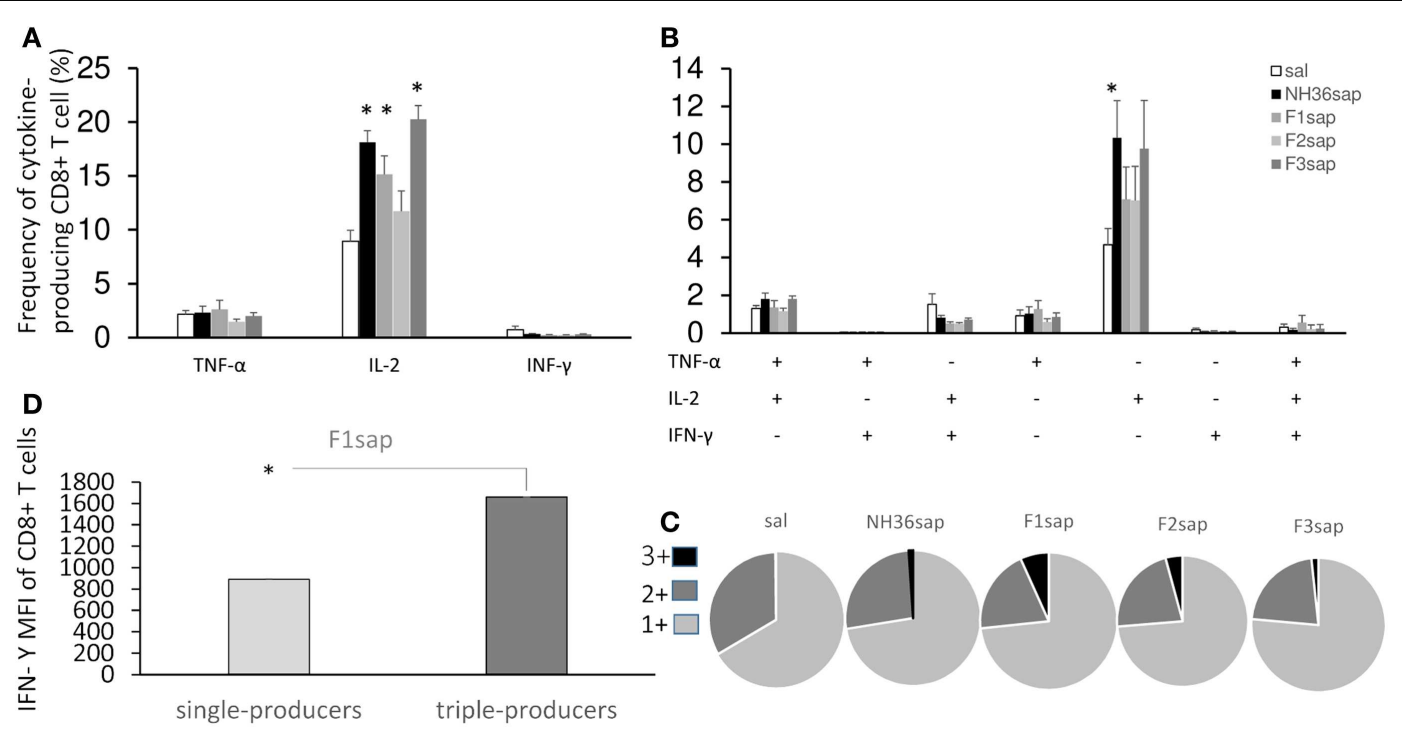

FIGURE 6 | Multifunctional analysis discloses the magnitude and quality of the $\mathrm{CD}^{+} \mathbf{T}$ cell response. $\mathrm{NH} 36$-specific cytokine production from $\mathrm{CD}^{+} \mathrm{T}$ cells of spleens of immunotherapy treated and control mice 9 weeks after infection (A-C). Multiparameter flow cytometry was used to determine (A) the total frequency of IFN- $\gamma-$, IL-2-, or TNF- $\alpha$-producing CD8 ${ }^{+} \mathrm{T}$ cells, (B) the frequency of cells expressing each of the seven possible combinations of IFN- $\gamma, \mathrm{IL}-2$, and
TNF- $\alpha,(\mathbf{C})$ the magnitude of the IFN- $\gamma$ secretion expressed by its median intensity fluorescence (MFI) in single cytokine and triple-cytokine $\mathrm{CD}^{+} \mathrm{T}$ cell producers and (D) the fraction of the total response comprising cells expressing all three cytokines (3+), any two cytokines $(2+)$, or any one cytokine $(1+)$. Results shown as the mean \pm SE of two independent experiments with $n=6-7$ in each experiment. * Significant differences from saline treated controls.
$R=-0.5367 ; p=0.0057$ ) were negatively correlated to the sizes of footpad lesions and the number of parasites in lesions, respectively.

Furthermore, quantifying the fraction of the total cytokine response of CD8 $\mathrm{T}$ cells comprising three $(3+)$, any two $(2+)$, or any one $(1+)$ cytokine (Figure $6 \mathrm{C}$ ), we found that while almost no triple labeled cells were detected in the saline controls $($ mean $=0.31 \%)$, this proportion increased in all vaccinated groups and exhibited the highest values in the F1sap vaccinated mice $(6.75 \%)$. We also found that $72-76 \%$ of the response to all treatments was $1+$ cell and from 20 to $32 \%$ was $2+$ cell. The proportion of the $3+$ labeled CD8 $+\mathrm{T}$ cells increased therefore at the expense of the $2+$ cell population (Figure 6C).

Regarding the magnitude of the immune response and in agreement with the highest frequency of triple-producers cells in F1sap vaccinated mice (Figure 6C), we noted a 1,859-fold increase in MFI for IFN- $\gamma$ in $\mathrm{CD}^{+} \mathrm{T}$ cells that secrete all the three cytokines when compared to the single cytokine-producing $\mathrm{CD}^{+} \mathrm{T}$ cells (Figure 6D), only in mice treated with the F1sap vaccine (Figure 6D).

As an alternative method to calculate the magnitude of the response, the iMFI values were additionally obtained by multiplying the frequency of the single cytokine producer $\mathrm{CD} 4^{+} \mathrm{T}$ cells and their MFI of single cytokine producers (Figure 7A). The F3 vaccine enhanced the iMFI-IL-2 and, together with the NH36 vaccine, also the iMFI-TNF- $\alpha$ values over the respective saline controls. There was not any significant variation in the magnitude of the response (iMFI) of $\mathrm{CD}^{+} \mathrm{T}$ cells for any cytokine by any of the vaccines (Figure 7B).

Collectively, our multifunctional analysis revealed that the immunotherapy treatment with NH36 peptide vaccines determined that the IL-2, TNF- $\alpha$, and TNF- $\alpha-I L-2-C D 4+$ and $-\mathrm{CD}^{+} \mathrm{T}$ cells were predictive of protection and immunotherapeutic potential of the vaccines and that protection improved as the CD4 responses shifted from $1+$ to $2+$ and the CD 8 responses shifted qualitatively from $1+$ to $3+$.

\section{DISCUSSION}

Several epitopes for T cell lymphocytes and antibodies where predicted along the whole sequence of NH36 but they have different levels of immunogenicity in prophylaxis against $L$. chagasi infection (48). The calculation of the surface area of the NH36 model revealed that the sequences of the F3 and F1 peptides are the most exposed and this suggests they have a greater availability for lysosome or proteaimmunosome enzymes, and hence, the enhanced probability of being presented by the MHC receptors. The F3 peptide, which has the highest number of predicted epitopes for $\mathrm{CD} 4^{+}$ T cells and antibodies (48), has the largest surface area and, is the target of the strongest cellular and humoral immune response against L. amazonensis (in this investigation) and L. chagasi (48). On the other hand, the lower access of the F2 domain to the surface area explains its lower immunogenicity in the L. chagasi (48) and L. amazonensis infection models, despite the prediction of one epitope for $\mathrm{CD}^{+}$, two for $\mathrm{CD} 8^{+} \mathrm{T}$ cells, and two for antibodies in its sequence (48).

After immunotherapy of L. amazonensis infection, only the F3 vaccine stands out as the most potent inducer of IgG and IgG2a anti-NH36 antibodies, while the IgG2b and IgG1 antibodies were equally enhanced by the F1, F2, and F3 vaccines. Interestingly, the $\mathrm{F} 1$ vaccine was less capable than the $\mathrm{F} 3$ vaccine in sustaining the IgG2a response. Additionally, the F2 vaccine induced an increase 

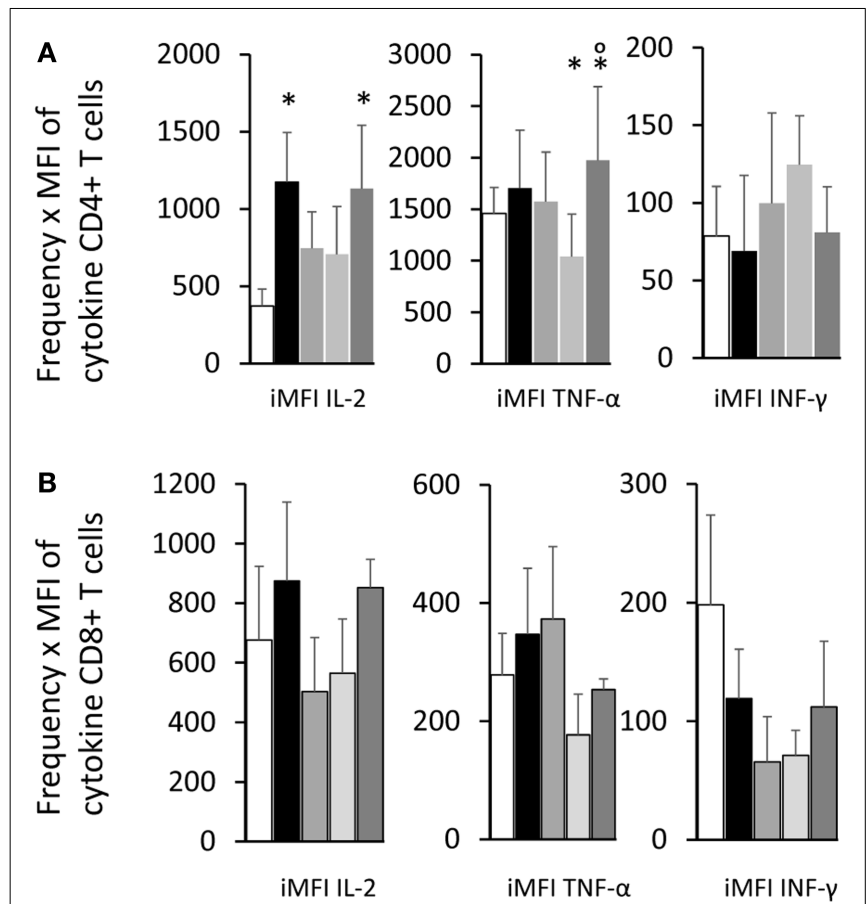

FIGURE 7 | Total functional response of the single cytokine producer T cells. By multiplying the frequency by the MFI of the single cytokine producer $T$ cells, we calculated the $\mathrm{MMFI}$ that reflects the total functional response of the population. Single cytokine producer $\mathrm{CD}^{+}(\mathbf{A})$ and $\mathrm{CD}^{+} \mathrm{T}$ cells (B). Results shown as the mean \pm SE of two independent experiments with $n=6-7$ in each experiment. * Significant differences from saline treated controls.

in IgG1 and IgG2b antibodies, which indicates the advancement of infection and is not correlated to therapeutic protection. We conclude that the most important epitopes for anti-NH36 antibodies generated after immunotherapy of L. amazonensis or prophylaxis against L. chagasi infection (48) are located in F3. F3 is then the target of the anti-Leishmania cross-specific humoral response of mice (48), and the antibody target of humans and dogs with VL (49) and of dogs vaccinated with Leishmune ${ }^{\circledR}(17)$. Since the antibodies generated by the Leishmune ${ }^{\circledR}$ vaccine in dogs reacted mostly with the F3 epitopes (48) and block the transmission of VL in the insect vector $(18,19)$, the identification of these cross-reactive immunogenic sequences in F3 might also help in blocking the transmission of CL.

The IDR to the lysate of L. amazonensis after immunotherapy was enhanced by the F3 and NH36 vaccines, similarly to what was detected before and after infection by $L$. chagasi (48). IDR is a well known correlate of protection that is expected to be absent in patients with VL (6) and DCL (7), who show immunosuppression, but present in cured individuals $(6,7)$, or after generation of vaccine protection $(16,17,48,54,55)$ or in patients with CL caused by L. braziliensis, which, on the contrary, show a strong $\mathrm{TH} 1$ response (8). In the selection of candidates for clinical trials of vaccines against CL, IDR is the main criteria for exclusion, as it indicates sensitization due to previous contact with the parasite (56). The description of the F3 vaccine and the NH36 vaccine as good enhancers of the IDR response of mice infected with $L$. amazonensis infection is important for the future development of defined cross-protective vaccines since: (1) L. amazonensis causes both CL and DCL $(2,7)$ individuals with DCL are commonly anergic, showing diminished or absent immune responses to Leishmania antigens $(3,7)$ and $(3)$ the single human vaccine licensed for immunotherapy of CL leishmaniasis is based on a L. amazonensis crude vaccine (15).

Additionally, as described for mice prophylaxis against VL and CL (48) the F3 vaccine was the most therapeutic against L. amazonensis, reducing the size of footpad lesions and the parasite load. A significant, although different, therapeutic effect was induced by the F1 vaccine. While both vaccines induced high secretion of the pro-inflammatory cytokines IFN- $\gamma$ and TNF- $\alpha$ by splenocytes, only the $\mathrm{F} 3$ vaccine exhibited the typical TH1 response with reduced levels of IL-10. The epitope prediction programs disclosed the existence of three epitopes for $\mathrm{CD} 4{ }^{+}$in the $\mathrm{F} 3$ and two in the F1 sequences, respectively. The $\mathrm{CD}^{+} \mathrm{T}$ cell epitope prediction program disclosed the highest affinity for the YPPEFKTKL epitope in F1 and no epitope in F3 (48). Accordingly and as described for VL (48), an in vivo depletion assay recently demonstrated that, protection against L. amazonensis infection is mediated by a TH1 $\mathrm{CD} 4{ }^{+} \mathrm{T}$ cell driven response to $\mathrm{F} 3$ and $\mathrm{a} \mathrm{CD} 8^{+} \mathrm{T}$ cell mediated response to the $\mathrm{F} 1$ domain (57).

In agreement with the above mentioned responses, Seder et al. (51), when describing immune correlates for vaccine-elicited protection against $\mathrm{CL}$, stated that a $\mathrm{CD} 4^{+} \mathrm{T}$-Helper 1-type response is considered necessary and even sufficient for infection by L. major, while $\mathrm{CD}^{+} \mathrm{T}$ cells are considered to have an important role in protection following natural infection and may be important for optimizing vaccine efficacy. Their model involves the earliest single secretion of TNF- $\alpha$ and of IL-2, followed by the development of double producers (TNF- $\alpha$ and IL-2) and by the later tripleproducers of IFN- $\gamma$-TNF- $\alpha$-IL-2 that can persist as memory or effector $\mathrm{CD}^{+} \mathrm{T}$ cells. In agreement with that our work revealed as a correlate of protection, the increase of total frequencies of TNF- $\alpha$ and IL-2, single and double producers of IL-2-TNF CD4 ${ }^{+}$ $\mathrm{T}$ cells while the work of Darrah et al. (52) indicated the triplepositive CD4 ${ }^{+}$T cells. This fact could suggest that the MML of $L$. major live vaccines promotes a more mature condition of immune protection. However, while Darrah et al. (52) described the correlation between the triple-cytokine producers and protection only post-vaccination, our analysis disclosed the correlates after challenge with L. amazonensis and immunotherapy. Indeed, there is no description of immune correlates for the protection by the MML vaccine after challenge with L. major (52). It is worth noting that it is more difficult to generate protection and disclose the immune correlates after the establishment of infection than before. Furthermore, while Darrah et al. (52), used cells of draining lymph nodes of C57BL/6 mice, inoculated with L. major intradermally in the ear, we used splenocytes of Balb/c mice inoculated with L. amazonensis in the footpads. Our approach reveals the state of the systemic cellular immunity. The different antigen and adjuvant composition of the vaccines could also account for the differences.

In contrast to Darrah et al. (52), we did not find a correlation between the frequencies of IFN- $\gamma^{+}$-producer cells and protection, and their frequencies were very low. In agreement with Darrah 
et al. (52), however, after immunotherapy with the F3 and F1 vaccines, we observed a progressive increase in the MFI values of IFN- $\gamma$ as the degree of functionality increased from single- to triple-cytokine producers, indicating that IFN- $\gamma$ might also represent a contribution to the cellular immune response against $L$. amazonensis. Another reason for the detection of low frequencies of IFN- $\gamma$-CD4 ${ }^{+}$producers by ICS might be the time of in vitro incubation. After $72 \mathrm{~h}$, the IFN- $\gamma$ might have already been secreted and therefore would no longer be inside the cells. The detection of increased amount of IFN- $\gamma$ in the supernatants of the same cells, of mice treated with the NH36, F1, or F3 vaccines confirms that hypothesis. Furthermore, the time of in vitro incubation might also be the reason for the higher frequencies of CD4 ${ }^{+}(30-40 \%)$ and $\mathrm{CD}^{+}{ }^{+}$cytokine producers cells $(20 \%)$. In the work of Darrah et al. (52), in vitro incubation lasted for $2 \mathrm{~h}$ only and the frequencies of $\mathrm{T}$ cells ranged from 0 to $1 \%$.

An important role of the $\mathrm{CD}^{+} \mathrm{T}$ cells in protection against CL $(51,58)$ and VL $(59)$ has been reported. Although the NH36 vaccine induced a $\mathrm{CD} 4^{+} \mathrm{T}$ cell mediated protection or therapy against VL in mice $(43,47)$ and dogs $(46,60)$, the recombinant NH36-saponin vaccine showed equal contributions of $\mathrm{CD}^{+}$and $\mathrm{CD}^{+} \mathrm{T}$ cells in protection for mice against VL (48) with the F3 being responsible for the $\mathrm{CD}^{+}{ }^{+}$response to $\mathrm{VL}$ (48) and CL and the $\mathrm{F} 1$ being responsible for the main $\mathrm{CD}^{+} \mathrm{T}$ cell driven protection against L. amazonensis (57).

According to Seder et al. (51), following activation, the naïve $\mathrm{CD} 8^{+} \mathrm{T}$ cells fully differentiate into activated effector $\mathrm{CD} 8^{+} \mathrm{T}$ cells that secrete IFN- $\gamma$, most with cytolytic activity, which can further differentiate into $\mathrm{CD}^{+} \mathrm{T}$ effect memory cells $\left(\mathrm{T}_{\mathrm{EM}}\right)$ secreting IFN- $\gamma$-TNF- $\alpha$, either directly, or after a step of conversion, to $\mathrm{CD}^{+}$central memory cells $\left(\mathrm{T}_{\mathrm{CM}}\right)$ which are triple-cytokine producers (IFN- $\gamma^{+}-$TNF- $\alpha^{+}-$IL- $2^{+}$). Therefore, the induction of IL-2 in $\mathrm{CD}^{+} \mathrm{T}$ cells is detected at a later time and is lost in chronic infections (51). In contrast to CD4 ${ }^{+} \mathrm{T}$ cells, it is considered very rare to find $\mathrm{CD} 8^{+} \mathrm{T}_{\mathrm{EM}}$ cells that produce IL-2. The enhanced ability of $\mathrm{CD}^{+}{ }^{+} \mathrm{T}_{\mathrm{CM}}$ cells to produce IL- 2 has been shown to confer improved protection compared with $\mathrm{CD}^{+} \mathrm{T}_{\mathrm{EM}}$ cells against a systemic viral challenge (61). Our results of immunotherapy of $L$. amazonensis infection with the F1-saponin vaccine gain relevance since frequencies of total and single IL- $2^{+} \mathrm{CD}^{+} \mathrm{T}$ cell producers were significantly increased, were predictive of the therapeutic effect and the percentages of triple-cytokine producers were also increased. We recently demonstrated that protection against $L$. amazonensis infection is mediated by the $\mathrm{CD}^{+} \mathrm{T}$ cell response induced by the F1 vaccine (57). Williams et al. (62) showed the IL-2 signaling to pathogen-specific $\mathrm{CD}^{+} \mathrm{T}$ cells is required for the generation of robust secondary responses, programing the development of $\mathrm{CD}^{+}$memory $\mathrm{T}$ cells capable of full secondary expansion. Our results suggest that the F1 domain, which contains the highest affinity epitope of the $\mathrm{NH} 36$ for $\mathrm{CD}^{+}$T cells (48), might be important for the development of $\mathrm{CD}^{+} \mathrm{T}_{\mathrm{CM}}$ cells (51), which through the high secretion of IL-2, or TNF or IL-2TNF actively contribute to the cure of the established infection. The intensity of IFN- $\gamma$ secretion by triple-producers, in our investigation, also proved to be above the levels of single producers, indicating the progressive increase in the MFI values of IFN- $\gamma$ in F1sap treated mice as the degree of functionality increased.
The F1sap vaccine was also a determinant in the increased secretion of IFN- $\gamma$ by CD4 ${ }^{+}$triple-cytokine producers, in the increased frequencies of total and double TNF- $\alpha$ and IL- 2 producers and in the secretion of IFN- $\gamma$ and TNF- $\alpha$ into the splenocyte supernatants indicating the induction of a TH1 response. However, mice treated with the $\mathrm{F} 1$ vaccine also showed a high secretion of IL-10 by splenocytes. While in VL IL-10 is considered to be the marker of the severe immunosuppressive disease (5, 63), IL-10 in human CL has been shown to be related to the pathology of the disease as well as the control of the parasite (64). Recently, the frequency and functional capacity of Tregs were evaluated in chronical patients with CL and in asymptomatic subjects (65). Although, the chronical patients presented higher frequencies of Tregs in peripheral blood and higher expression of FOXP3 at leishmanin skin test sites, their $\mathrm{CD} 4{ }^{+} \mathrm{CD} 25^{+}$cells were less capable of suppressing antigen specific IFN- $\gamma$ secretion by effector cells compared with asymptomatic infected individuals. At the end of the treatment, both the frequency of $\mathrm{CD} 4{ }^{+} \mathrm{CD} 25^{\text {hi }} \mathrm{CD} 127^{-}$cells and their capacity to inhibit proliferation and IFN- $\gamma$ secretion increased and coincided with healing of CL lesions suggesting that the restored IL-10 secretion by Tregs was involved in the cure of the disease (65). The authors suggested that the Tregs impaired function was evidence of pathogenesis of CL and Treg subsets would be relevant in designing immunotherapeutic strategies for recalcitrant dermal leishmaniasis $(65) . \mathrm{CD}^{+} \mathrm{CD} 25^{+}$regulatory $\mathrm{T}$ cells have also been shown to restrain pathogenic responses during L. amazonensis infection (66). The simultaneous induction of an immunotherapeutic effect and the increase in the secretion of IL-10 determined by the F1 peptide might also be related to the stimulation of Treg subsets and to the presence of epitopes for Tregs along its sequence.

In our investigation, a significant decrease of IL-10 levels was found in the supernatants of whole splenocytes of F3 vaccinated mice. A population of $\mathrm{IFNy}^{+}$-producing $\mathrm{CD} 4^{+} \mathrm{T}$ cells that also produce IL-10 has been identified in VL as a feature of T cell differentiation (67). Expanded numbers of these cells were associated with disease progression (67). Conventional CD11 chi DCs that produce both IL-10 and IL-27 It have also been shown to promote the production of IL-10 by these effector $\mathrm{CD} 4^{+} \mathrm{T}$ cells (67). In our investigation, besides CD4 ${ }^{+} \mathrm{T}$ cells, DCs could also be the source of the IL-10 secretion detected in splenocyte supernatants. These types of DCs were also present in our mice model of CL infection. If that is the case, we could assume that immunotherapy with the F3 peptide formulated with saponin, could promote the direct shifting of DCs away from an IL-10 producing phenotype, which is more frequent in the untreated controls, to a pro-Th1 IL-12 producing phenotype, with reduced IL-10 secretion (67).

An alternative source of IL-10, in L. amazonensis infected mice, could be natural killer (NK) cells. In mice infected with $L$. donovani, NK cells are found in the spleen and liver hepatic granulomas (68). They are responsible for suppressing the host resistance to the parasite, through the secretion of IL-10, which is present in early infection. In mice with an established infection, the IL-10 mRNA acquires more stability and IL-10 secretion by NK is enhanced (68). In the context of CL leishmaniasis, IL-10 has been shown to be essential for L. major persistence (69). NK cells were also more frequent in relapsed than in cured cases of mucosal leishmaniasis 
and a decrease in NK cells and in IL-10 levels was observed after therapy (70).

A few other antigens have been proposed as potential synthetic vaccines against leishmaniasis $(59,71-73)$. The $\mathrm{kmp}-11$ protein of $L$. donovani has epitopes recognized by human CD8 ${ }^{+}$lymphocytes and by many different HLA receptors (59). The Leish110f fusion protein of L. major, on the other hand, induced mice protection mediated by $\mathrm{CD}^{+}$lymphocytes (72). Recently, an adenovirus based vaccine comprising a synthetic HASPB gene composed of 10 repeats, linked to the KMP-11 gene, was obtained and assayed in the therapy of $L$. donovani infected mice therapeutics (73). The synthetic gene was cloned using humanized codons. The immunogenicity increased if the vaccine was administered in the footpads instead of subcutaneously. A detailed study of the contribution of the epitopes of HASPB protein was performed. After therapeutic vaccination, the IgG1 and IgG2a antibody responses were enhanced and IFN- $\gamma$-CD $8^{+} \mathrm{T}$ cell response, mainly to HASPB, became apparent. Interestingly, a single dose of the vaccine reduced the parasite growth in spleens by $66 \%$ (73).

Immunotherapy for the treatment of human VL leishmaniasis has recently been recommended (74). The C-terminal and $\mathrm{N}$-terminal domains of NH36 of L. donovani are the basis of the strong immunotherapeutic effect against $L$. amazonenis infection. Our findings contribute to the design of defined vaccines for cross-protection against CL leishmaniasis.

\section{AUTHOR CONTRIBUTIONS}

Conceived and designed the experiments: Clarisa Beatriz Palatnikde-Sousa, Dirlei Nico. Acquisition, analysis, and interpretation of data: Dirlei Nico, Daniele Crespo Gomes, Iam Palatnik-de-Sousa, Alexandre Morrot, Marcos Palatnik, Clarisa Beatriz Palatnikde-Sousa. Wrote the paper: Clarisa Beatriz Palatnik-de-Sousa. Final approval of the last version of the manuscript to be published: Clarisa Beatriz Palatnik-de-Sousa, Dirlei Nico, Daniele Crespo Gomes, Iam Palatnik-de-Sousa, Alexandre Morrot, Marcos Palatnik.

\section{ACKNOWLEDGMENTS}

This work was supported by Conselho Nacional de Desenvolvimento Científico e Tecnológico (CNPQ, Fellowships 3012152007-3, 302039/2010-4, 559756/2010-0 and grant 404400/2012-4) and by Fundação de Amparo à Pesquisa do Estado de Rio de Janeiro (FAPERJ, grants 102733/2008 and 102957/2011, and Fellowships E-26/102415/2010 and E-26/110535/2010). David Straker is gratefully acknowledged for the English language revision of this manuscript and Professors Rafael Linden and Pedro Geraldo Pascutti, of the Instituto de Biofísica Carlos Chagas Filho, Universidade Federal do Rio de Janeiro, for their important contribution on the design of the molecular model.

\section{REFERENCES}

1. Kedzierski L, Zhu Y, Handman E. Leishmania vaccines: progress and problems. Parasitology (2006) 133(Suppl S):87-112. doi:10.1017/S0031182006001831

2. Alvar J, Vélez ID, Bern C, Herrero M, Desjeux P, Cano J, et al. Leishmaniasis worldwide and global estimates of its incidence. PLoS One (2012) 7(5):e35671. doi:10.1371/journal.pone.0035671

3. Da-Cruz AM, Bittar R, Mattos M, Oliveira-Neto MP, Nogueira R, PinhoRibeiro V, et al. T-cell-mediated immune responses in patients with cutaneous or mucosal leishmaniasis: long-term evaluation after therapy. Clin Diagn Lab Immunol (2002) 9(2):251-6.

4. Das A, Ali N. Vaccine development against Leishmania donovani. Front Immunol (2012) 3:99. doi:10.3389/fimmu.2012.00099

5. Ganguly S, Das NK, Panja M, Pal S, Modak D, Rahaman M, et al. Increased levels of interleukin-10 and IgG3 are hallmarks of Indian post-kala-azar dermal leishmaniasis. J Infect Dis (2008) 197(12):1762-71. doi:10.1086/588387

6. Stober CB, Jeronimo SM, Pontes NN, Miller EN, Blackwell JM. Cytokine responses to novel antigens in a peri-urban population in Brazil exposed to Leishmania infantum chagasi. Am J Trop Med Hyg (2012) 87(4):663-70. doi:10.4269/ajtmh.2012.12-0180

7. Silveira FT, Lainson R, Corbett CE. Further observations on clinical, histopathological, and immunological features of borderline disseminated cutaneous leishmaniasis caused by Leishmania (Leishmania) amazonensis. Mem Inst Oswaldo Cruz (2005) 100(5):525-34. doi:10.1590/S0074-02762005000500013

8. Schnorr D, Muniz AC, Passos S, Guimaraes LH, Lago EL, Bacellar O, et al. IFN$\gamma$ production to Leishmania antigen supplements the Leishmania skin test in identifying exposure to L. braziliensis infection. PLoS Negl Trop Dis (2012) 6(12):e1947. doi:10.1371/journal.pntd.0001947

9. Carvalho AM, Magalhães A, Carvalho LP, Bacellar O, Scott P, Carvalho EM. Immunologic response and memory $\mathrm{T}$ cells in subjects cured of tegumentary leishmaniasis. BMC Infect Dis (2013) 13:529. doi:10.1186/1471-2334-13-529

10. Sundar S. Drug resistance in Indian visceral leishmaniasis. Trop Med Int Health (2001) 6(11):849-54. doi:10.1046/j.1365-3156.2001.00778.x

11. Maltezou HC. Drug resistance in visceral leishmaniasis. J Biomed Biotechnol (2010) 2010:617521. doi:10.1155/2010/617521

12. Convit J, Castellanos PL, Ulrich M, Castés M, Rondón A, Pinardi ME, et al. Immunotherapy of localized, intermediate, and diffuse forms of American cutaneous leishmaniasis. J Infect Dis (1989) 160(1):104-15. doi:10.1093/infdis/160. 1.104

13. Castes M, Moros Z, Martinez A, Trujillo D, Castellanos PL, Rondon AJ, et al. Cell-mediated immunity in localized cutaneous leishmaniasis patients before and after treatment with immunotherapy or chemotherapy. Parasite Immunol (1989) 11(3):211-22. doi:10.1111/j.1365-3024.1989.tb00660.x

14. Cabrera M, Blackwell JM, Castes M, Trujillo D, Convit J, Shaw MA. Immunotherapy with live BCG plus heat killed Leishmania induces a $\mathrm{T}$ helper 1-like response in American cutaneous leishmaniasis patients. Parasite Immunol (2000) 22(2):73-9. doi:10.1046/j.1365-3024.2000.00278.x

15. Mayrink W, Botelho AC, Magalhães PA, Batista SM, Lima Ade O, Genaro O, et al. Immunotherapy, immunochemotherapy and chemotherapy for American cutaneous leishmaniasis treatment. Rev Soc Bras Med Trop (2006) 39(1):14-21. doi:10.1590/S0037-86822006000100003

16. Silva VO, Borja-Cabrera GP, Correia Pontes NN, Paraguai de Souza E, Luz KG, Palatnik M, et al. A phase III trial of efficacy of the FML-vaccine against canine kala-azar in an endemic area of Brazil (São Gonçalo do Amarante, RN). Vaccine (2000) 19(9-10):1082-92.

17. Borja-Cabrera GP, Santos FN, Bauer FS, Parra LE, Menz I, Morgado AA, et al. Immunogenicity assay of the Leishmune ${ }^{\circledR}$ vaccine against canine visceral leishmaniasis in Brazil. Vaccine (2008) 26(39):4991-7. doi:10.1016/j.vaccine.2008. 07.029

18. Palatnik-de-Sousa CB, Barbosa AF, Oliveira SM, Nico D, Bernardo RR, Santos WR, et al. The FML-vaccine against canine visceral leishmaniasis: from the second generation to the synthetic vaccine. Expert Rev Vaccines (2008) 7(6):833-51. doi:10.1586/14760584.7.6.833

19. Saraiva EM, de Figueiredo Barbosa A, Sanots FN, Borja-Cabrera GP, Nico D, Souza LP, et al. The FML-vaccine (Leishmune ${ }^{\circledR}$ ) against canine visceral leishmaniasis: a transmission blocking vaccine. Vaccine (2006) 24(13):2423-31. doi:10.1016/j.vaccine.2005.11.061

20. Palatnik-de-Sousa CB, Silva-Antunes I, Morgado Ade A, Menz I, Palatnik M, Lavor C. Decrease of the incidence of human and canine visceral leishmaniasis after dog vaccination with Leishmune ${ }^{\circledR}$ in Brazilian endemic areas. Vaccine (2009) 27(27):3505-12. doi:10.1016/j.vaccine.2009.03.045

21. Araújo MS, de Andrade RA, Vianna LR, Mayrink W, Reis AB, Sathler-Avelar $\mathrm{R}$, et al. Despite Leishvaccine and Leishmune trigger distinct immune profiles, their ability to activate phagocytes and CD8+ T-cells support their high-quality immunogenic potential against canine visceral leishmaniasis. Vaccine (2008) 26(18):2211-4. doi:10.1016/j.vaccine.2008.02.044

22. Araújo MS, de Andrade RA, Sathler-Avelar R, Teixeira-Carvalho A, Andrade MC, Vianna LR, et al. T-cell-derived cytokines, nitric oxide production by 
peripheral blood monocytes and seric anti-Leishmania (Leishmania) chagasi IgG subclass patterns following immunization against canine visceral leishmaniasis using Leishvaccine and Leishmune. Vaccine (2009) 27(7):1008-17. doi:10.1016/j.vaccine.2008.11.104

23. Araújo MS, de Andrade RA, Sathler-Avelar R, Magalhães CP, Carvalho AT, Andrade MC, et al. Immunological changes in canine peripheral blood leukocytes triggered by immunization with first or second generation vaccines against canine visceral leishmaniasis. Vet Immunol Immunopathol (2011) 141(12):64-75. doi:10.1016/j.vetimm.2011.02.007

24. Marciani DJ. Vaccine adjuvants: role and mechanisms of action in vaccine immunogenicity. Drug Discov Today (2003) 8(20):934-43. doi:10.1016/S13596446(03)02864-2

25. Borja-Cabrera GP, Cruz Mendes A, Paraguai de Souza E, Hashimoto Okada LY, de A Trivellato FA, Kawasaki JK, et al. Effective immunotherapy against canine visceral leishmaniasis with the FML-vaccine. Vaccine (2004) 22(17-18):2234-43. doi:10.1016/j.vaccine.2003.11.039

26. Santos FN, Borja-Cabrera GP, Miyashiro LM, Grechi J, Reis AB, Moreira $\mathrm{MA}$, et al. Immunotherapy against experimental canine visceral leishmaniasis with the saponin enriched-Leishmune vaccine. Vaccine (2007) 25(33):6176-90. doi:10.1016/j.vaccine.2007.06.005

27. de Lima VM, Ikeda FA, Rossi CN, Feitosa MM, Vasconcelos RO, Nunes CM, et al. Diminished CD4+/CD25+ T cell and increased IFN-gamma levels occur in dogs vaccinated with Leishmune in an endemic area for visceral leishmaniasis. Vet Immunol Immunopathol (2010) 135(3-4):296-302. doi:10.1016/j.vetimm.2009. 12.008

28. Borja-Cabrera GP, Santos FN, Santos FB, Trivellato FA, Kawasaki JK, Costa AC, et al. Immunotherapy with the saponin enriched-Leishmune vaccine versus immunochemotherapy in dogs with natural canine visceral leishmaniasis. Vaccine (2010) 28(3):597-603. doi:10.1016/j.vaccine.2009.09.071

29. Oliveira-Freitas E, Casas CP, Borja-Cabrera GP, Santos FN, Nico D, Souza LO, et al. Acylated and deacylated saponins of Quillaja saponaria mixture as adjuvants for the FML-vaccine against visceral leishmaniasis. Vaccine (2006) 24(18):3909-20. doi:10.1016/j.vaccine.2006.02.034

30. Leach A, Vekemans J, Lievens M, Ofori-Anyinam O, Cahill C, Owusu-Agyei $\mathrm{S}$, et al. Design of a phase III multicenter trial to evaluate the efficacy of the RTS,S/AS01 malaria vaccine in children across diverse transmission settings in Africa. Malar J (2011) 10:224. doi:10.1186/1475-2875-10-224

31. Asante KP, Abdulla S, Agnandji S, Lyimo J, Vekemans J, Soulanoudjingar S, et al. Safety and efficacy of the RTS,S/AS01E candidate malaria vaccine given with expanded-programme-on-immunisation vaccines: 19 month follow-up of a randomised, open-label, phase 2 trial. Lancet Infect Dis (2011) 11(10):741-9. doi:10.1016/S1473-3099(11)70100-1

32. RTS,S Clinical Trials Partnership; Agnandji ST, Lell B, Fernandes JF, Abossolo BP, Methogo BG, et al. A phase 3 trial of RTS,S/AS01 malaria vaccine in African infants. N Engl J Med (2012) 367:2284-95. doi:10.1056/NEJMoa1208394

33. Palatnik de Sousa CB, Gomes EM, de Souza EP, dos Santos WR, de Macedo SR, de Medeiros LV, et al. The FML (fucose mannose ligand) of Leishmania donovani: a new tool in diagnosis, prognosis, transfusional control and vaccination against human kala-azar. Rev Soc Bras Med Trop (1996) 29(2):153-63.

34. Iovane E, Giabbai B, Muzzolini L, Matafora V, Fornili A, Minici C, et al. Structural basis for substrate specificity in group I nucleoside hydrolases. Biochemistry (2008) 47(15):4418-26. doi:10.1021/bi702448s

35. Versées W, Goeminne A, Berg M, Vandemeulebroucke A, Haemers A, Augustyn $\mathrm{K}$, et al. Crystal structures of T. vivax nucleoside hydrolase in complex with new potent and specific inhibitors. Biochim Biophys Acta (2009) 1794(6):953-60. doi:10.1016/j.bbapap.2009.02.011

36. Santana DM, Borja-Cabrera GP, Paraguai de Souza E, Sturm NR, Palatnik de Sousa CB, Campbell DA. Nucleoside hydrolase from Leishmania (L.) donovani is an antigen diagnostic for visceral leishmaniasis. Mol Biochem Parasitol (2002) 120(2):315-9. doi:10.1016/S0166-6851(02)00010-5

37. Lukes J, Mauricio IL, Schönian G, Dujardin JC, Soteriadou K, Dedet JP, et al. Evolutionary and geographical history of the Leishmania donovani complex with a revision of current taxonomy. Proc Nat Acad Sci U S A (2007) 104(22):9375-80. doi:10.1073/pnas.0703678104

38. Mauricio IL, Yeo M, Baghaei M, Doto D, Pratlong F, Zemanova E, et al. Towards multilocus sequence typing of the Leishmania donovani complex: resolving genotypes and haplotypes for five polymorphic metabolic enzymes (ASAT, GPI, NH1, NH2, PGD). Int J Parasitol (2006) 36(7):757-69. doi:10.1016/j.ijpara.2006. 03.006
39. Cui L, Rajasekariah GR, Martin SK. A nonspecific nucleoside hydrolase from Leishmania donovani: implications for purine salvage by the parasite. Gene (2001) 280(1-2):153-62. doi:10.1016/S0378-1119(01)00768-5

40. Blast-Basic Local Alignment Search Tool. National Institute of Heath (NIH) (2014). Available from: http://blast.ncbi.nlm.nih.gov/Blast.cgi

41. Paraguai de Souza E, Bernardo RR, Palatnik M, Palatnik de Sousa CB. Vaccination of Balb/c mice against experimental visceral leishmaniasis with the GP36 glycoprotein antigen of Leishmania donovani. Vaccine (2001) 19(2324):3104-15. doi:10.1016/S0264-410X(01)00031-7

42. Al-Wabel MA, Tonui WK, Cui L, Martin SK, Titus RG. Protection of susceptible BALB/c mice from challenge with Leishmania major by nucleoside hydrolase, a soluble exo-antigen of Leishmania. Am J Trop Med Hyg (2007) 77(6): 1060-5.

43. Aguilar-Be I, Zardo RS, Paraguai de Souza E, Borja-Cabrera GP, Rosado-Vallado M, Mut-Martin M, et al. Cross-protective efficacy of a prophylactic Leishmania donovani DNA vaccine against visceral and cutaneous murine leishmaniasis. Infect Immun (2005) 73(2):812-9. doi:10.1128/IAI.73.2.812-819.2005

44. Chalé-Balboa WG, Mut-Martin M, Ramirez-Sierra MJ, Garcia-Miss MR, Dumonteil E. A combination DNA vaccine encoding nucleoside hydrolase 36 and glycoprotein 63 protects female but not male hamsters against Leishmania mexicana. Parasite (2009) 16(3):227-30. doi:10.1051/parasite/2009163227

45. Souza LOP, Palatnik de Sousa CB. The nucleoside hydrolase DNA vaccine VR1012NH36 in prophylactic vaccination against mice tegumentar leishmaniasis. Proc Vaccinol (2009) 1(1):120-3. doi:10.1016/j.provac.2009.07.022

46. Borja-Cabrera GP, Santos FB, Picillo E, Gravino E, Manna L, Palatnik de Sousa CB. Nucleoside hydrolase DNA vaccine against canine visceral leishmaniasis. Proc Vaccinol (2009) 1(1):104-9. doi:10.1016/j.provac.2009.07.019

47. Gamboa-León R, Paraguai de Souza E, Borja Cabrera GP, Santos FN, Miyashiro LM, Pinheiro RO, et al. Immunotherapy against visceral leishmaniasis with the nucleoside hydrolase-DNA vaccine of L. donovani. Vaccine (2007) 24(22):4863-73. doi:10.1016/j.vaccine.2006.03.005

48. Nico D, Claser C, Travassos LR, Palatnik M, Soares IS, Rodrigues MM, et al. Adaptive immunity against Leishmania nucleoside hydrolase maps its Cterminal domain as the target of the CD4+ T cell-driven protective response. PLoS Negl Trop Dis (2010) 4(11):e866. doi:10.1371/journal.pntd.0000866

49. Costa MM, Penido M, dos Santos MS, Doro D, de Freitas E, Michalik MS, et al. Improved canine and human visceral leishmaniasis immunodiagnosis using combinations of synthetic peptides in enzyme-linked immunosorbent assay. PLoS Negl Trop Dis (2012) 6(5):e1622. doi:10.1371/journal.pntd.0001622

50. Shi W, Schramm VL, Almo SC. Nucleoside hydrolase from Leishmania major. Cloning, expression, catalytic properties, transition state inhibitors, and the 2.5å crystal structure. J Biol Chem (1999) 274(30):21114-20. doi:10.1074/jbc.274. 30.21114

51. Seder RA, Darrah PA, Roederer M. T cell quality in memory and protection: implications for vaccine design. Nat Rev (2008) 8(4):247-58. doi:10.1038/ nri2274

52. Darrah PA, Patel DT, De Luca PM, Lindsay RWB, Davey DF, Flynn BG, et al. Multifunctional $\mathrm{T}_{\mathrm{H}} 1$ cells define a correlate of vaccine-mediated protection against Leishmania major. Nat Med (2007) 13(7):843-50. doi:10.1038/nm1592

53. Manna L, Reale S, Viola E, Vitale F, Manzillo VF, Pavone LM, et al. Leishmania DNA load and cytokine expression levels in asymptomatic naturally infected dogs. Vet Parasitol (2006) 142(3-4):271-80. doi:10.1016/j.vetpar.2006. 06.028

54. Kamil AA, Khalil EA, Musa AM, Modabber F, Mukhtar MM, Ibrahim ME, et al. Alum-precipitated autoclaved Leishmania major plus bacille Calmette-Guérrin, a candidate vaccine for visceral leishmaniasis: safety, skin-delayed type hypersensitivity response and dose finding in healthy volunteers. Trans $R$ Soc Trop Med Hyg (2003) 97(3):365-8. doi:10.1016/S0035-9203(03)90171-4

55. Khalil EA, El Hassan AM, Zijlstra EE, Mukhtar MM, Ghalib HW, Musa B, et al. Autoclaved Leishmania major vaccine for prevention of visceral leishmaniasis: a randomised, double-blind, BCG-controlled trial in Sudan. Lancet (2000) 356(9241):1565-9. doi:10.1016/S0140-6736(00)03128-7

56. Antunes CM, Mayrink W, Magalhaes PA, Costa CA, Melo MN, Dias M, et al. Controlled field trials of a vaccine against New World cutaneous leishmaniasis. Int J Epidemiol (1986) 15(4):572-80. doi:10.1093/ije/15.4.572

57. Nico D, Gomes DC, Alves-Silva MV, Freitas EO, Rodrigues MM, Palatnik M, et al. Cross-protective immunity to Leishmania amazonensis is mediated by CD4+ and CD8+-epitopes of Leishmania donovani nucleoside hydrolase terminal domains. Front Immunol (2014) 5:189. doi:10.3389/fimmu.2014.00189 
58. Rodrigues MM, Boscardin SB, Vasconcelos JR, Hiyane MI, Salay G, Soares IS. Importance of CD8 T cell-mediated immune response during intracellular parasitic infections and its implications for the development of effective vaccines. An Acad Bras Cienc (2003) 75(4):443-68. doi:10.1590/S0001-37652003000400005

59. Basu R, Roy S, Walden P. HLA class I-restricted T cell epitopes of the kinetoplastid membrane protein-11 presented by Leishmania donovani-infected human macrophages. J Infect Dis (2007) 195(9):1373-80. doi:10.1086/513439

60. Borja-Cabrera GP, Santos FB, Nico D, Gravino AE, Manna L, Palatnik M, et al. The Leishmune ${ }^{\circledR}$ 's nucleoside hydrolase DNA vaccine as an aid inimmunotherapy of canine visceral leishmaniasis. Proc Vaccinol (2012) 6:64-73. doi:10.1016/j.provac.2012.04.009

61. Wherry EJ, Blattman JN, Murali-Krishna K, van der Most R, Ahmed R. Viral persistence alters CD8 T-cell immunodominance and tissue distribution and results in distinct stages of functional impairment. J Virol (2003) 77(8):4911-27. doi:10.1128/JVI.77.8.4911-4927.2003

62. Williams MA, Tyznik AJ, Bevan MJ. Interleukin-2 signals during priming are required for secondary expansion of CD8+ memory T cells. Nature (2006) 441(7095):890-3. doi:10.1038/nature04790

63. Gama ME, Gomes CM, Silveira FT, Laurenti MD, Gonçalves Eda G, Silva AR, et al. Severe visceral leishmaniasis in children: the relationship between cytokine patterns and clinical features. Rev Soc Bras Med Trop (2013) 46(6):741-5. doi:10.1590/0037-8682-0203-2013

64. Costa DL, Guimarães LH, Cardoso TM, Queiroz A, Lago E, Roselino AM, et al. Characterization of regulatory $\mathrm{T}$ cell (Treg) function in patients infected with Leishmania braziliensis. Hum Immunol (2013) 74(12):1491-500. doi:10.1016/j. humimm.2013.08.269

65. Rodriguez-Pinto D, Navas A, Blanco VM, Ramírez L, Garcerant D, Cruz A, et al. Regulatory $\mathrm{T}$ cells in the pathogenesis and healing of chronic human dermal leishmaniasis caused by Leishmania (Viannia) species. PLoS Negl Trop Dis (2012) 6(4):e1627. doi:10.1371/journal.pntd.0001627

66. Ji J, Masterson J, Sun J, Soong L. CD4 CD25 regulatory T cells restrain pathogenic responses during Leishmania amazonensis infection. J Immunol (2005) 174(11):7147-53. doi:10.4049/jimmunol.174.11.7147

67. Owens BM, Beattie L, Moore JW, Brown N, Mann JL, Dalton JE, et al. IL10-producing Th1 cells and disease progression are regulated by distinct $\mathrm{CD}_{11 \mathrm{c}^{+}}$cell populations during visceral leishmaniasis. PLoS Pathog (2012) 8(7):e1002827. doi:10.1371/journal.ppat.1002827

68. Maroof A, Beattie L, Zubairi S, Svensson M, Stager S, Kaye PM. Posttranscriptional regulation of II10 gene expression allows natural killer cells to express immunoregulatory function. Immunity (2008) 29(2):295-305. doi:10.1016/j. immuni.2008.06.012

69. Belkaid Y, Piccirillo CA, Mendez S, Shevach EM, Sacks DL. CD4+CD25+ regulatory T cells control Leishmania major persistence and immunity. Nature (2002) 420(6915):502-7. doi:10.1038/nature01152

70. Tuon FF, Gomes-Silva A, Da-Cruz AM, Duarte MI, Neto VA, Amato VS. Local immunological factors associated with recurrence of mucosal leishmaniasis. Clin Immunol (2008) 128(3):442-6. doi:10.1016/j.clim.2008.05.007

71. Palatnik-de-Sousa CB. Vaccines for leishmaniasis in the fore coming 25 years. Vaccine (2008) 26(4):1709-24. doi:10.1016/j.vaccine.2008.01.023

72. Bertholet S, Goto Y, Carter L, Bhatia A, Howard RF, Carter D, et al. Optimized subunit vaccine protects against experimental leishmaniasis. Vaccine (2009) 27(50):7036-45. doi:10.1016/j.vaccine.2009.09.066

73. Maroof A, Brown N, Smith B, Hodgkinson MR, Maxwell A, Losch FO, et al. Therapeutic vaccination with recombinant adenovirus reduces splenic parasite burden in experimental visceral leishmaniasis. J Infect Dis (2012) 205(5):853-63. doi:10.1093/infdis/jir842

74. Musa AM, Noazin S, Khalil EA, Modabber F. Immunological stimulation for the treatment of leishmaniasis: a modality worthy of serious consideration. Trans $R$ Soc Trop Med Hyg (2010) 104(1):1-2. doi:10.1016/j.trstmh.2009.07.026

Conflict of Interest Statement: The authors have declared that there are no competing interests. This work is related to the pendent Patent PI1015788-3, INPI, Brazil.

Received: 28 February 2014; accepted: 27 May 2014; published online: 11 June 2014. Citation: Nico D, Gomes DC, Palatnik-de-Sousa I, Morrot A, Palatnik Mand Palatnikde-Sousa CB (2014) Leishmania donovani nucleoside hydrolase terminal domains in cross-protective immunotherapy against Leishmania amazonensis murine infection. Front. Immunol. 5:273. doi: 10.3389/fimmu.2014.00273

This article was submitted to Immunotherapies and Vaccines, a section of the journal Frontiers in Immunology.

Copyright (c) 2014 Nico, Gomes, Palatnik-de-Sousa, Morrot, Palatnik and Palatnikde-Sousa. This is an open-access article distributed under the terms of the Creative Commons Attribution License (CC BY). The use, distribution or reproduction in other forums is permitted, provided the original author(s) or licensor are credited and that the original publication in this journal is cited, in accordance with accepted academic practice. No use, distribution or reproduction is permitted which does not comply with these terms. 